\title{
An Experimental Study on the Innovative CDIO Method in English Language Teaching
}

\author{
Ahmet Yusuf ${ }^{1}$, Filiz Yalçin Tilfarlioğlu ${ }^{1}$ \\ ${ }^{1}$ Gaziantep University, Gaziantep, Turkey \\ Correspondence: Ahmet Yusuf, Gaziantep University, Gaziantep, Turkey.
}

Received: June 23, $2020 \quad$ Accepted: July 23, $2020 \quad$ Online Published: July 29, 2020

doi:10.11114/jets.v8i9.4949 URL: https://doi.org/10.11114/jets.v8i9.4949

\begin{abstract}
This experimental study is an attempt to bring a new perspective and a new teaching method CDIO (Conceiving, Designing, Implementing, and Operating) to the ELT field. The CDIO method was applied in the 11th grade in a private high school in Diyarbakir, Turkey. The students were subjected to a pretest before the treatment process and to a posttest after the process. The treatment procedures and materials were prepared according to the CDIO curriculum and standards. The treatment process lasted for fifteen weeks for the experimental group while the control group continued learning English without being exposed to the CDIO teaching method. Subsequently, the collected data was analyzed with the assistance of IBM SPSS Statistics 23.0 to see whether the CDIO methodology has effective results on the students' performance or not. After the data was collected and analyzed, the results showed that the students performed better after learning English using CDIO in the rate of $14.45 \%$, where the mean score of the pretest was 71.66 while the mean score of the posttest was 86.23. Moreover, the results exhibit that the participants' fulfillment developed in grammar, vocabulary and reading comprehension skills. Accordingly, there is a great improvement in the students' performance of the experimental group. Also, the outcomes show that the CDIO has played a big role in developing the students' level and has shown a positive effect on learning English. Finally, it is expected from this research to open the door for schools and faculties of teaching English to adopt the CDIO approach and apply it in their programs.
\end{abstract}

Keywords: CDIO method, CDIO standards, grammar, vocabulary and reading skills, experimental research

\section{Introduction}

Learning a language is something hard and teaching a language is harder. In the current life, many people tend to learn languages as the big world has become a small cottage. After decades of technological developments and modernity, the world has become more interconnected than ever, that is what we call globalization. The conception of globalization refers to the interdependence of the countries educationally, economically, culturally, and pedagogically. And to be in the race, people need to learn languages to keep pace with the other generations. It's no hidden to anybody that the English language is the dominant language so far. More than that, the demand for English is remarkably increasing all over the world, not only in the field of teaching but also in many other fields like translating, trading, communicating with the outside world, business, tourism, and so forth.

And as a matter of fact, learning English theoretically and through traditional methods does not help too much in practical life, as a result, the employers cannot find the qualified graduates that they need in their work. Moreover, many English graduates cannot find a good job after graduating because they lack experience and qualifications (Wenwen \& Yunfei, 2018). This means that there is a gap between the real world demands and English graduates; thus, this gap must be closed. So finding a practical way of teaching English is necessary and crucial to cover the demands of English in real life. Therefore, educators have been concerning about how to teach English and how to find appropriate teaching methods to assist the students to learn English effectively.

Scholars have different views on the best way of teaching and learning languages. Some teaching approaches require learning grammar rules and vocabularies lists, other approaches Stimulate the students to memorize and imitate sentences in dialogues (root learning), yet some others motivate the students to use natural language among each other in a task or a project (Lightbown, Spada 2013). While Holliday focused on culture in second language acquisition (SLA) and sees it as an instrument in language learning, more than that Holliday looks at the classroom as a culture and through its knowledge and skills are transferred (Holliday, 1994). Additionally, the dispute about the authentic vs the 
artificial language in applied linguistic language teaching (ALLT) took a place from the 1970s afterward. Where Waters (2009) stated that using authentic language (real language by natives) may increase the learners' motivation and may have a significant pedagogic function. While Richards (2006), declares:

What is important in writing materials for EFL learners is not necessarily native speaker usage, but

rather what will provide the means of successful communication both within and outside the

classroom. This means providing learners with a repertoire of well selected vocabulary, sentence

patterns and grammar, as well as a stock of communication strategies

how native-speakers ask

for and give directions is largely irrelevant....... my goal is to give them the resources to have successful experiences using English for simple classroom activities. Whether or not they employ native

speaker-like language to do so is irrelevant (p. 22).

Furthermore, some scholars alerted the educators that they should not forget about the individual differences(ID) of the learners and their different capacities, Dörnyei (2005) talked about that in detail and he mentioned many factors that affect the psychology of the learners in SLA like language aptitude, personality, motivation, and self-motivation, willingness to communicate (WTC), learner beliefs, anxiety, self-esteem, creativity, intelligence, temperament, mood, learning styles, language learning strategies, self-regulatory capacity, etc. Some other researchers like Ur (2011) went that it is not only the methodology of teaching plays a big rule but also further factors influence the process of teaching such as education ministries, school principals, classroom management, socio-cultural background, the learner's relationships, and their preferences, time available for preparation, personalities and motivation. Then Ur adds that these features have impacts on learning more than how languages are taught.

As we see there are controversial discussions about learning languages and these discussions are not going to end, that's because every educational society has its own properties. As a result, inventing new methods for teaching English is a continuous case. Community Language Learning (CLL), The Direct Method (DM), The Grammar Translation Method (GTM), The Audio-Lingual Method (ALM), Suggestopedia, The Total Physical Response Method (TPR), The Communicative Approach (CA), etc., these are the most famous ELT methods. But the new trend is some academics are trying to bring some new methods from different fields and apply them to English language teaching, and one of these methods is CDIO.

CDIO stands for Conceive Design Implement and Operate. CDIO method has been in use for almost two decades in four continents, in many different countries, in more than 120 schools and universities around the world, so why do not the Turkish education institutions bring this method and use it? And why do not they try something new and innovative?

\section{Background}

At first, only the engineering programs applied the CDIO teaching model but now language teaching programs are adopting it as a practical way of teaching. CDIO teaching method takes the notion as a transporter in Successive steps: from the conception, investigation, and improvement, operating, recycling then leading the learners to learn actively, inducing the students to naturally connect the learned material with the professional knowledge and finally sharpening their capabilities to produce an outcome and involve in the practical society effectively (Gu, Lu, \& Shen, 2008). Furthermore, Zhu (2010) thinks that teaching languages should combine linguistic skills and Professional skills, and he believes that the interdisciplinarity of the CDIO can achieve that. Crawley, Malmqvist, Östlund, Brodeur, and Edström (2014) note that most of the CDIO features are related to experiential learning.

\section{CDIO Standards}

In the year 2004 the CDIO initiative created twelve standards, these standards describe the features of the CDIO program and they present the guiding lines of the educational system and they display the wanted goals and achievements of the CDIO program (CDIO Standards v. 2.0. 2010) for a further visit (http://www.cdio.org).

For each standard, there will be:

Description: it will explain the connotation and the significance of the standard and elaborates on the important terms and expressions and gives background information.

Rationale: it points out the causes of adopting this standard, and these causes are dependent on educational research. In addition to that, the rationale shows up how this standard is differentiating the CDIO method from the other educational methods.

\subsection{Standard 1: The Context}

"Adopting the following principle: product, process, and system lifecycle development and deployment (Conceiving, 
Designing, Implementing and Operating) are the context for education" (CDIO Standards v. 2.0, 2010, p.3).

Description: The lifecycle system consists of four stages, the conceiving stage comprises the plans, and the customer needs analysis, the project strategy, and developing conceptual ideas. The designing stage concerns about making the designs, the layouts, the patterns, the styles, and the delineation of what is going to be implementing. The third stage, the Implementing stage, focuses on the conversion of the design into output and produce, in addition to that, it focuses on the processing, the manufacturing process, testing, and the training session. The last phase, the operating stage, uses the product to reach the wanted goal and worth.

Rationale: The alumni of CDIO (the graduates) must be able to Conceive, Design, Implement and Operate values, process, and product in a team group circumference. The students who are using CDIO should participate in operating the processes and in developing the product while they are learning and do the same when move to professional life in any organization they work for.

\subsection{Standard 2: CDIO Learning Outcomes}

"Specific, detailed learning outcomes for personal and interpersonal skills, product, process, and system building skills, as well as disciplinary knowledge,_consistent with program goals and validated by program stakeholders" (CDIO Standards v. $2.0,2010$, p.4).

Description: According to the CDIO syllabus, the learning outcomes are the skills and the knowledge that the students should know and can be able to apply when they finish the education program. In the first section of the CDIO syllabus, the learning findings are divided into personal and interpersonal dexterities. In the second section, the personal learning outcomes emphasize critical thinking, problems solving skills, dictates of conscience, moral codes, inventive thinking skills, and dexterity and knowledge discovery. While in the third section of the CDIO syllabus the interpersonal learning outcomes concentrate on the communication in foreign languages, social relations, and the colleagues' interactions, cooperative interaction, synergy, partnership, and teamwork. In contrast, the fourth section the system building skills concentrate on the four pillars of CDIO conceiving, designing, implementing, and operating. All of the above will be checked and reviewed by the stakeholders after graduation from the CDIO program, therefore the stakeholders play a crucial role in determining the success criteria in CDIO learning outcomes.

Rationale: Building accurate learning outcomes can help the students in gaining strong foundations that may help them in their professional future.

\subsection{Standard 3: Integrated Curriculum}

"A curriculum designed with mutually supporting disciplinary courses, with an explicit plan to integrate personal and interpersonal skills, product, process, and system building skills" (CDIO Standards v. 2.0, 2010, p.5).

Description: Producing, processing, system establishing competence, personal and interpersonal dexterity, and professional knowledge intermingling with experiential learning is the essence of the integrated curriculum of the CDIO program.

Rationale: Producing, processing, system establishing competence, personal and interpersonal dexterity, professional knowledge, and experiences learning must not be an extra part of a fully completed curriculum but rather it must be an integral part of the curriculum. And to get the best possible results from the integrated curriculum and the disciplinary knowledge, the curriculum should exploit the time in the dual-use ordinance. Another key point, the educational institution plays a big function in making a suitable incorporated curriculum by adding the proper disciplinary skills.

\subsection{Standard 4: Introduction to Education}

"An introductory course that provides the framework for education practice in product, process, and system building, and introduces essential personal and interpersonal skills" (CDIO Standards v. 2.0, 2010, p.6).

Description: As a matter of fact, the beginning is always important, therefore, the preparatory course for learning anything needs to be well prepared and it should give a framework for the whole program. The framework must show the tasks and the plans of the whole educational program and it must prepare the students starting from simple to hard techniques. In other words, the students should be prepared to solve more advanced problems and produce more advanced expressions in the aimed language.

Rationale: The first goal of the introductory course is to increase the motivation of the learners and engage their interests in learning the target language.

\subsection{Standard 5: Design-Build Experiences}

"A curriculum that includes two or more design-implement experiences, including one at a basic level and one at an advanced level" (CDIO Standards v. 2.0, 2010, p.7). 
Description: The expression design-implement indicates that there is inventing and producing some new activities, new ideas, and new techniques in learning a language. And the producing here passes through two stages, the first one is the conceiving stage and the second stage is the designing-implementing stage. To rephrase it, the learners convert what is conceptual to something tangible, what is on paper to practical activities to the target language.

Rationale: the environment which depends on hands-on approach learning creates a fantastic atmosphere for learning and producing from one hand and designing and building on the other hand.

\subsection{Standard 6: CDIO Workspaces}

"Education Workspaces and laboratories that support and encourage hands-on learning of product and system building, disciplinary knowledge, and social learning" (CDIO Standards v. 2.0, 2010, p.8).

Description: Physical learning atmosphere comprises classical education stuff like schoolrooms, halls, auditoriums, laboratories, and workplaces. These workplaces and workshops focus on hands-on learning and practical learning. Where the students interact and work together, share the learning process and that is what we call social learning.

Rationale: The workplaces, workshops, and any learning atmosphere that focuses on hands-on learning and practical learning ere essential resources for conceiving, designing, implementing, and operating.

\subsection{Standard 7: Integrated Learning Experiences}

"Integrated learning experiences that lead to the acquisition of disciplinary knowledge, as well as personal, interpersonal, and product and system building skills" (CDIO Standards v. 2.0, 2010, p.9).

Description: Integrated learning experiences are educational methods that boost the disciplinary knowledge learning at the same time with personal and interpersonal dexterity and system establishing dexterity.

Rationale: The second and the third standards i.e. the curriculum designing and learning outcomes can be perceived only if there are congruous educational methods that exploit the students' time in a dual-use ordinance. The educational institutions with the help of integrated expertise learning are capable to help the students to grasp the target language effectively and efficiently.

\subsection{Standard 8: Active Learning}

"Teaching and learning based on active experiential learning methods" (CDIO Standards v. 2.0, 2010, p.10).

Description: Active learning approaches catch the students thinking and their ability for problem-solving and decision making, analyzing and evaluating ideas, group debating, and feedback among one another.

Rationale: By means of catching the learners in contemplating fresh notions and concepts, the learners not only learn but also realize and understand what and how they learned. Moreover, using active learning manners motivate the learners to learn the language smoothly and make them shape learning lifelong habits.

\subsection{Standard 9: Enhancement of CDIO Based Educational Institutions Competence}

"Actions that enhance school competence in personal, interpersonal, and product and system building skills" (CDIO Standards v. 2.0, 2010, p.11).

Description: CDIO programs supply assistance for educational institutions to upgrade their adequacy in the personal, interpersonal, individual, social, product, and system building skills as explained in the second standard. They improve these ingenuities in the context of teaching and learning languages in a professional way.

Rationale: the teaching languages schools can integrate the skills of CDIO with disciplinary knowledge and that is to keep pace with fast technological development and to keep updating the language teaching and learning skills.

\subsection{Standard 10: Enhancement of Faculty Teaching Competence}

"Actions that enhance faculty competence in providing integrated learning experiences, in using active experiential learning methods, and in assessing student learning" (CDIO Standards v. 2.0, 2010, p.12).

Description: CDIO programs supply assistance for the educational institutions to upgrade their competence in three aspects. Firstly, in the integrated learning experiences as illustrated in the seventh standard, secondly, in the lively and experimental learning as explained in the eighth standard, thirdly, in evaluating students learning as it clarified in the eleventh standard.

Rationale: If the CDIO program wants to assure the significance of the three following fields teaching, learning, and evaluation it should adopt sufficient resources for the schools' development in these fields.

\subsection{Standard 11: Learning Assessment}

"Assessment of student learning in personal, interpersonal, and product and system building skills, as well as in 
disciplinary knowledge" (CDIO Standards v. 2.0, 2010, p.13).

Description: Assessing the learners' achievement means measuring to what extent the learners have fulfilled the wanted level in grasping the target language. Evaluating the learning outcomes declaim the CDIO skills, producing, processing, system establishing competence, personal and interpersonal dexterity, professional knowledge, and experiences learning. The assessment process may contain rating scales, spoken or written tests, watching the students' performance, colloquies, and self-appraisal.

Rationale: If we give a value to the CDIO skills, producing, processing, system establishing competence, personal and interpersonal dexterity, professional knowledge, and experiences learning then we have to assess and evaluate them. Sometimes different results need different kinds of assessment, for example, we can evaluate with verbal or written tests for the disciplinary knowledge outcomes, and we can use recorded observations design-implement skills, and so on. The last thing to add is that using different ways of evaluation enhances the assessment's reliability and validity.

\subsection{Standard 12: CDIO Program Evaluation}

"A system that evaluates programs against these twelve standards, and provides feedback to students, faculty, and other stakeholders for the purposes of continuous improvement" (CDIO Standards v. 2.0, 2010, p.14).

Description: A CDIO program has to be evaluated in relation to the $12^{\text {th }}$ CDIO Standards. An overall evaluation of the CDIO should be done and compare it to the awaited outcomes. More than that, the report or the evidence of the whole evaluation can be presented as feedback to the students, teachers, alumni, employers, and the educational institution's administration.

Rationale: All in all, the main goal of the evaluation is to decide the program's efficiency and effectiveness according to the planned aims. The evidence that has been collected through the program evaluation is considered as a criterion of the program development. Even more, if a big number of the learners claim that they did not reach some of the intended results, an initiative to search for the reasons and making the required changes could be launched.

\section{CDIO Syllabus}

The first version of the CDIO syllabus was designed in 2001 and it has proved its success in more than 100 programs in international level. The general aim of the CDIO syllabus is to build a set of knowledge, abilities, and skills that the stakeholders and the society want from the next generations. To add more, the syllabus can be also used as a foundation base for building new educational processes and curriculums for specific purposes (Crawley 2001; Crawley, Lucas, Malmqvist \& Brodeur 2011).

There is a consensus about the CDIO syllabus, which is a catalog of some topics that are suitable for the learners' skills, comprehension, understanding, and knowledge. Also, the CDIO syllabus represents the store and the resource for the educational institutions trying to apply for the CDIO program and it represents the final outcomes of the program and the skills that the students should have when they graduate (Bankel et al., 2002).

The syllabus has five levels of details; the following table resembles the CDIO syllabus at the first level of detail:

Table 1. The CDIO syllabus at the first level of detail (Crawley and et al., 2011, p.6)

The first level of detail

1.Technical Knowledge and Logics

2. Personal and Professional Skillfulness

2. Personal and Professional Skillfulness

4. Conceiving, Designing, Implementing and Operating (CDIO)

Nevertheless, the first version of the syllabus was successful, there was a need to change it and that was emerging for two reasons. The first was because of the knowledge's classification changing, and the second was because of the inquiring of the users of the syllabus about the missing skills and competencies (Delors et al., 1996; Passow, 2007; Crawley et al., 2014). The table below shows the CDIO syllabus at the second level of detail. 
Table 2. The CDIO syllabus at the second level of detail (Crawley and et al., 2011, p.5)

\begin{tabular}{|c|c|}
\hline \multicolumn{2}{|c|}{ The second level of detail } \\
\hline $\begin{array}{l}\text { 1. disciplinary knowledge and } \\
\text { reasoning }\end{array}$ & $\begin{array}{l}\text { 3. interpersonal skills: teamwork and } \\
\text { communication }\end{array}$ \\
\hline 1.1 knowledge of language use and science & 3.1 teamwork \\
\hline 1.2 core fundamental knowledge of engineering & 3.2 communications \\
\hline 1.3 advanced engineering & 3.3 communications in foreign \\
\hline fundamental knowledge, methods and tools & languages \\
\hline 2 personal and professional skills and attributes & 4 conceiving, designing, \\
\hline 2.1 analytical reasoning and problem solving & implementing, and operating \\
\hline 2.2 experimentation, investigation & systems in the enterprise, \\
\hline and knowledge discovery & societal and environmental \\
\hline 2.3 system thinking & context \\
\hline 2.4 attitudes, though and learning & 4.1 external, societal and \\
\hline 2.5 ethics, equity and other & environmental context \\
\hline \multirow{5}{*}{ Responsibilities } & 4.2 enterprise and business context \\
\hline & $\begin{array}{l}4.3 \text { conceiving, systems engineering, and } \\
\text { management }\end{array}$ \\
\hline & 4.4 designing \\
\hline & 4.5 implementing \\
\hline & 4.6 operating \\
\hline
\end{tabular}

The first information of the syllabus was collected from some categories, focus group discussions, workshops, document research, peer reviews, and surveys. So the initial pace of collecting the content of the CDIO syllabus was focus group discussions which included: MIT faculty (the Massachusetts Institute of Technology in the USA), current MIT students, and industry leaders in the USA, and senior academics from other USA universities. Through the discussion, the groups were introduced to the following question "what are the skills and the knowledge the learners should know when they finish their course or school?" And by the same token, the surveys were applied in for precincts: old graduates, young graduates, and MIT faculty and industry leaders in the USA. So these surveys and discussions equally with the peer reviews and workshops help to improve the CDIO syllabus concerning the clarity and conciseness, comprehensiveness, and productiveness (Bankel, Berggren, Blom, Crawley, Östlund \& Wiklund 2002; Bankel et al., 2005).

The syllabus consists of four sections, in the first section of the syllabus, the disciplinary knowledge identifies the learning results as personal and impersonal dexterities, system establishing dexterity, producing, and processing. While in the second section the personal learning results emphasize critical thinking, problems solving skills, dictates of conscience, moral codes, inventive thinking skills, and dexterity and knowledge discovery. Yet in the third section of the CDIO syllabus, the interpersonal learning outcomes concentrate on the communication in foreign languages, social relations, and the colleagues' interactions, cooperative interaction, synergy, partnership, and teamwork. In contrast, the fourth section the system building skills concentrate on the four pillars of the CDIO (conceiving, designing, implementing, and operating). To see the third and fifth level of details of the CDIO syllabus visit (http://cdio.org/).

\section{Applicability of CDIO on the ELT Field}

Applying CDIO on English Language Teaching can be done by applying seven practical abilities improved by CDIO teaching mode according to CDIO syllabus and standards. Leshan Normal University in China shows how the CDIO teaching method improves different abilities of English major students. (Wenwen, X., Yunfei, G. 2018):

\subsection{Practical Knowledge of English}

As in the $7^{\text {th }}$ standard of CDIO (Integrated Learning Experiences) and the first section of the CDIO syllabus (Disciplinary Knowledge and Reasoning), in the CDIO teaching method, the students acquire practical knowledge from doing some projects under the direction of the teacher. To carry out the projects the students first need to understand the text and absorb the knowledge by themselves. And if they face some problems they need to solve them by discussing the problems in the group and in case they still have some unsolved parts the teacher gives them some clues for help. 


\subsection{The Capability of Finding and Solving Problems}

This ability matches with the $8^{\text {th }}$ standard of CDIO (Active Learning). The students learn how to find out the problems and try to solve them, the teacher will be just the guide for the projects. CDIO approach urges the students to solve their problems in many ways like:

Research: The students start to research the problem causes, collect information, and be familiar with it; the researching process could be online or asking the older colleagues or the more experienced people around them. So the CDIO builds problem solvers who can depend on themselves to find solutions for the problems they face from one hand and builds problem solvers who can avoid the problem before it happens in the future from the other hand.

Decision-making: Eventually, the students have to make decisions to solve the problems and in this case, they improve their decision-making capabilities.

Analysis: The opening move for solving any problem will start with analyzing and the students need to use their analytical tact to comprehend the problem and promote solutions.

Communication: For finding out a solution you need to communicate with the other and even when you find a solution you also need to communicate it in a proper way to avoid the misunderstanding and to fasten carrying out the solutions.

\subsection{Self-Learning Ability}

Unlike the other methods of teaching English, in the CDIO method students are motivated to understand the text by themselves to improve their Self-Learning Abilities and collect extra information about the topic to enrich their understanding. The self-driven learning process gives learning more meaning because it comes from a personal willingness. Additionally, self-learning becomes more enjoyable and brings better outcomes since the students are working hard for the sake of learning not for being their responsibility. Moreover, self-learning leads to curiosity, and when you have the curiosity that means you will search more and learn new information so that you increase your qualifications. Actually to learn by yourself successfully you have to specify your goals, your tools, and the way to assess yourself and to be ready to face the obstacles. (Karanja, 2017).

\subsection{Related Job Ability}

The students make projects related to their future employment field and practice them; this will help them to increase their abilities like teaching abilities, translating abilities, communication abilities, etc. This part matches with the $2^{\text {nd }}$ standard of CDIO (CDIO Syllabus Outcomes). The related job skills are significant for the CDIO method as it focuses on the stage after graduation, and it aims to graduate students with qualified job-related skills. English is almost used in each labor domain and it has become a passport through it you can enter any job country (Sri Durga, 2018). So having the communication skills in English and the job qualifications are the essence of what CDIO is seeking.

\subsection{Teamwork Spirit}

The CDIO syllabus focuses on the third section (Interpersonal Skills: Teamwork and Communication) on teamwork and the idea of sharing joy and thought with others. In the CDIO method, the teacher gives the students some projects and tasks related to their topic in the coursebook and the students need to do them in teams and groups, such activities will increase their unity, cooperation, and teamwork spirit. In other words, the CDIO concept stems from the proverb "Coming together is the beginning. Keeping together is progress. Working together is success" Henry Ford.

\subsection{Critical Thinking Ability}

In the CDIO approach students have to not just memorize the existing knowledge in their curriculum, but they should have their thinks and beliefs. Thereupon, the CDIO teachers do not expect the students to remember the whole details rather they expect them to think, observe, conceptualize, analyze, evaluate, communicate, give decisions, and gain experience. The students are taught that there is not only one specific answer for each question, instead, but they are also taught that there are open-ended questions which they need you to think critically about them. This will help the students to establish their own opinions and ideas and help them to take hard decisions and to continue improving their intellectual skills after graduation.

\subsection{Innovation Ability}

The students should not only improve their professional knowledge but also they have to improve their abilities of innovation. Accordingly, the CDIO method tries to create an innovative atmosphere and works to avail of the individual inventiveness of the students. To be innovative you need to be ready for change and you should not stop at any point in success. The innovative people do not have a limit for their successfulness and they are not satisfied with what they have achieved and they always seek better options and alternatives. The philosophy of the innovative people is "you commit suicide when you settle for second best." 


\section{The Experimental Study}

\subsection{The Research Questions}

Research Question \# 1 To what extent does the CDIO method raise the students' total score?

Research Question \# Does the gender factor have an effect on the experimental group after applying the CDIO teaching method?

Research Question \# 3 Is there a difference between the students who learned English through CDIO and the students who did not in terms of performance?

Research Question \# 4 To what extent can be using CDIO in English lessons of the eleventh-grade students boost their skills in:

1. Grammar

2. Vocabulary

3. Reading comprehension.

\subsection{Methodology, Research Design, and Procedures}

This research is an experimental method based research, and it depends on its procedures and principles to complete this study. This experimental study is comprised of two groups: experimental one which is consisted of 60 students from the $11^{\text {th }}$ grade distributed to three classrooms. And another group called the control group that has the same number of students and the same grade. The experimental group consists of three subgroups which they had given treatment in accordance to CDIO teaching approach standards. The control group did not take any treatment because it was created for comparison goals. Both groups experimental and control took a pretest at the beginning of the first semester of the educational year 2019/2020. Also, after finishing the treatment of the CDIO teaching method they were subjected to a posttest.

The treatment process lasted for fifteen weeks for the experimental group while the control group continued learning English according to the traditional way without exposing it to the CDIO teaching method. The students had six lessons per week each lesson for 40 minutes, so in total, they had been treated for 90-course hours. After finishing the treatment and the posttest the data were collected and analyzed with the help of IBM SPSS Statistics 23.0 to see whether the CDIO has effective results on the students' performance or not. The map of the study is shown in the following Figure1:

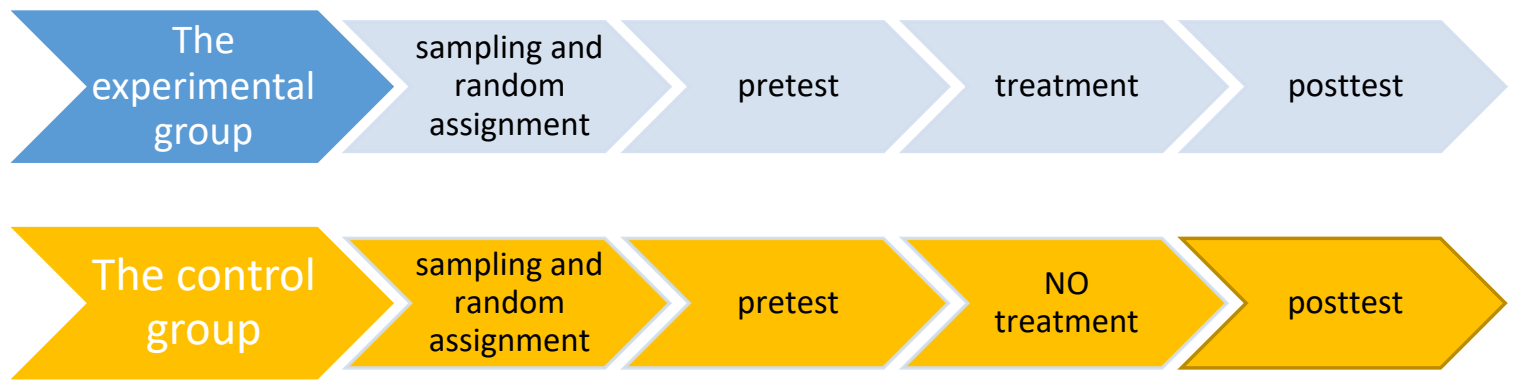

Figure 1. The map of the study

The participants of this study are juniors / 11th grade from Ortadoğu College, a private school in Diyarbakir / Turkey in the 2019 / 2020 academic year. The total number of the participants in this experimental research is 120 students, the males' number was 54 which forms $45 \%$ of the population of the study, while the females' number was 66 which forms $55 \%$ of the total number of the participants.

\subsection{The Treatment Process}

Firstly, only the experimental group received the CDIO treatment, while the control group did not receive any treatment from CDIO. Both groups used the same book (English File) for learning English but the difference is that the experimental group used the CDIO techniques and standards whereas the control group used the traditional learning way. Here, the researcher explains how to apply CDIO and explains some techniques that have been used in the treatment process.

\subsubsection{The Four Stages of the CDIO Lesson Technique}

The CDIO lesson has four stages and for each stage, there are two periods in the class and after the class and sometimes one additional period, which is before the class. It should be noted that the researcher benefitted from the Leshan University study's ideas and techniques in using CDIO in the language lessons as explained in (Wenwen \& Baoguo 2020). 
Conceive: In this stage, there is an overall preparation for the lesson where the students go into their groups for each group there is a name (names of some poets) and a leader. The groups will have a short time to check the topic of the lesson according to the instructions of the teacher. Here the students are allowed to use the internet, the Google research engine, the translator, and any software platform that can help them. Moreover, after the class, the students make a group discussion and make a plan.

Design: In this stage, the students collect information, learn cooperatively, and the teacher act as an observer, helps the students to understand the topic, and solves any possible problem. To give an example of the design stage in practice, let us see a sample from the first week of the treatment, the pronouns (please check Appendix G, the treatment weekly plan); here each group introduces one kind of the pronouns (subject pronouns, object pronouns, possessive pronouns, and the possessive adjectives) and gives some sentences as examples. For instance, Shakespeare group introduces the possessive pronouns (theirs, hers, ours, his, hers, yours, mine) and put them in sentences, etc. After the class, the group leaders divide the project into the members and the members do their utmost to complete their portions.

Implement: This is the stage of converting the collected data by the students into a presentation, where the group members discuss and exchange opinions until they reach a consensus to the ultimate presentation. The teacher in this stage assists the students in case of any obstacle or problem. Besides, after the class, the students try to relate what they have learned to their social life and put what they have learned into practice.

Operate: In this stage, each group presents their project to the classroom, the materials they used, the information they collected, and the strategy they used. Lastly, the final step is the evaluation, which goes through three phases. The first evaluation occurs within the group itself where the members sit, discuss, and evaluate themselves. The second evaluation is among the other groups, after watching one group presentation the other groups evaluate it on the evaluation notepaper. The last one is the instructor evaluation; the instructor evaluates each group and gives them some notes and comments so they can improve their next projects. In Table 3, there are specific details about the in-class and after-class activities and proceedings.

Table 3. The four stages of the CDIO lessons (Wenwen \& Baoguo 2020.p. 4)

\begin{tabular}{|c|c|c|c|c|c|}
\hline \multicolumn{6}{|c|}{ The four stages of the CDIO lessons } \\
\hline \multirow[t]{3}{*}{ Conceive } & In class & Get information & $\begin{array}{l}\text { Determine the } \\
\text { requirements }\end{array}$ & & \multirow{3}{*}{ Make a plan } \\
\hline & After class & $\begin{array}{l}\text { Make group } \\
\text { discussion }\end{array}$ & $\begin{array}{l}\text { Arrange the } \\
\text { labor division }\end{array}$ & $\begin{array}{l}\text { Predict the } \\
\text { achievement }\end{array}$ & \\
\hline & In class & $\begin{array}{l}\text { Study } \\
\text { independently }\end{array}$ & $\begin{array}{l}\text { Cooperate to } \\
\text { research }\end{array}$ & & \\
\hline Design & After class & $\begin{array}{l}\text { Sub-divide the } \\
\text { project }\end{array}$ & $\begin{array}{l}\text { Analyze the } \\
\text { sub-projects }\end{array}$ & Process data & \multirow[t]{2}{*}{$\begin{array}{l}\text { Learn related } \\
\text { technique }\end{array}$} \\
\hline \multirow{2}{*}{ Implement } & In class & $\begin{array}{l}\text { Actively } \\
\text { participate }\end{array}$ & $\begin{array}{l}\text { Be guided by } \\
\text { the teacher }\end{array}$ & & \\
\hline & After class & $\begin{array}{l}\text { Implement } \\
\text { technology }\end{array}$ & Integrate data & $\begin{array}{l}\text { Shape the } \\
\text { achievement }\end{array}$ & \multirow[t]{2}{*}{$\begin{array}{l}\text { Present the } \\
\text { achievement }\end{array}$} \\
\hline \multirow{2}{*}{ Operate } & In class & $\begin{array}{ll}\begin{array}{l}\text { Solve } \\
\text { problem }\end{array} & \text { the }\end{array}$ & $\begin{array}{l}\text { Present the } \\
\text { achievement in } \\
\text { class }\end{array}$ & & \\
\hline & After class & $\begin{array}{l}\text { Practice the } \\
\text { presentation }\end{array}$ & $\begin{array}{l}\text { Evaluate within } \\
\text { each group }\end{array}$ & $\begin{array}{l}\text { Evaluate other } \\
\text { groups }\end{array}$ & $\begin{array}{l}\text { Be evaluated by } \\
\text { the teacher }\end{array}$ \\
\hline
\end{tabular}

6.3.2 The Five Minutes Fast Share Technique

The five minutes fast share is a presentation at the beginning of the lesson given by a student about any topic the student chooses. The presentation must be installed in the classroom smartboard before the lesson. The student must finish on time, neither longer nor shorter than five minutes. Sometimes, two students could prepare a fast share and present it together. In this technique, the students improve their speaking skills and raise their vocabulary size; moreover, they increase their self-confidence and self-learning skills (Zheng, 2013). Furthermore, the researcher has prepared a rubric for evaluating the five minutes fast share as in Table 4. 
Table 4. The rubric of the five minutes fast share

\begin{tabular}{|c|c|c|c|}
\hline Criteria & $\begin{array}{l}\text { Admirable } \\
\text { ( } 2 \text { points) }\end{array}$ & $\begin{array}{l}\text { Agreeable } \\
\text { (1 point) }\end{array}$ & $\begin{array}{l}\text { Not agreeable } \\
\quad(0 \text { points })\end{array}$ \\
\hline Delivering & $\begin{array}{l}\text { When the student } \\
\text { delivers the information } \\
\text { effectively }\end{array}$ & $\begin{array}{l}\text { When the student } \\
\text { delivers the information } \\
\text { in a fair way }\end{array}$ & $\begin{array}{l}\text { When the student does } \\
\text { not deliver the } \\
\text { information effectively }\end{array}$ \\
\hline Preparing & $\begin{array}{l}\text { When the student is well } \\
\text { prepared }\end{array}$ & $\begin{array}{l}\text { When the student is } \\
\text { prepared in a fair way }\end{array}$ & $\begin{array}{l}\text { When the student is not } \\
\text { well prepared }\end{array}$ \\
\hline Timing & $\begin{array}{l}\text { When the student comes } \\
\text { on-time finishes on time } \\
\text { neither longer nor shorter }\end{array}$ & & $\begin{array}{l}\text { When the student comes } \\
\text { late or when the student } \\
\text { finishes before or after } \\
\text { the specified time }\end{array}$ \\
\hline Content & $\begin{array}{l}\text { When the content is rich } \\
\text { and prosperous }\end{array}$ & $\begin{array}{l}\text { When the content is good } \\
\text { and fair }\end{array}$ & $\begin{array}{l}\text { When the content is poor } \\
\text { and inadequate }\end{array}$ \\
\hline
\end{tabular}

6.3.3 The Group Lecturing Technique

In the required book, which is English File, in each unit, there are about two small articles or texts, and in the group lecturing technique, one group will present one article to the classroom. It is also expected from the group to prepare a presentation or handouts, Moreover, the members of the group need to explain the new vocabularies and the hard sentences to the classroom i.e. they will play the teacher's role in lecturing the articles of each unit in the required book. On some occasions, presenting the article needed two lessons to be finished (Zheng, 2013). Likewise, the fast share technique, the researcher has prepared a rubric to evaluate the students singly and as a group.

\subsubsection{The Social Interviewing Technique}

In this technique, each group needs to find an English speaker and make an interview with him or her about any suitable topic. The group members should prepare a sketch before the interview and each member should speak in the interview. After that, the students need to prepare a video and the transcript of the dialogue and present it in the classroom. Later on, the other groups evaluate the interview and the teacher evaluates and gives some suggestions. The social interviewing technique aims to improve the students speaking and listening skills (Zheng, 2013).

\subsubsection{The Impact of each Unit Technique}

This technique aims to improve the writing skills and the vocabulary size of the students. At the end of each unit, the researcher asks the students to write their impact on the unit. The students may relate the topics of the units to their life, they can give their opinions about the topics of the unit, or whatever they write about their favorite topics is acceptable. It is expected from the students to write at least one page with 12 font and the space between the lines is 1.5. Again, they will have an evaluation from the teacher and the teacher saves their writings in the portfolio of each student in the experimental group.

\subsubsection{The Class Dojo Technique}

Class dojo is a remote learning and communication platform and application specialized for the schools and the education usages; moreover, it is a tool for the students to have a self-assessment and a tool to reward the hard-working students in the classroom. In addition, class dojo provides a way of sharing among a whole classroom with connection with the parents under the supervision of the teacher in a safe way. In class dojo there is a password for each student provided by the teacher, what is more, the teacher can connect the parents so they can see their children activities in school. One more thing to add is class dojo is most suitable in the primary and secondary level and to some extent in the high school level. The researcher has noticed the positive effects of this technique and he recommends it.

\subsubsection{The Portfolio Technique}

The portfolio is a combination of the students' assignments and works through the treatment of this experimental study. There is a separate portfolio for each student and in the portfolio; there is the four-stage of CDIO documents and evaluations, the fast share documents, the group lecturing of the unit articles, the reflections of each unit, the social interviewing reports, and all the students' works during the treatment process.

It is very important here to mention that these techniques were prepared according to the CDIO standards and the researcher used these techniques to teach the experimental group only i.e. the control group did not see any of the CDIO techniques. 


\subsection{Data Analysis and Findings}

\subsubsection{The Impact of Applying CDIO on English Language Learning}

This part answers the first research question about the ability of the CDIO teaching model to raise the students' total score in the posttest. After finishing the treatment and carrying out the posttest, the data was collected and a paired samples t-test was applied to compare the outcomes of the pretest and the posttest of the experimental group. The results of the paired samples t-test show that there is a significant difference in the mean scores of the participants. The mean score of the pretest was 71.66 whilst the mean score of the posttest was 86.23 as exhibited in Table 5 .

Table 5. The mean scores of the pretest and posttest of the experimental group

\begin{tabular}{llcccc}
\hline & Mean & $\mathrm{N}$ & Std. Deviation & $\begin{array}{c}\text { Std. Error } \\
\text { Mean }\end{array}$ \\
\hline Pair 1 & & & & \\
& & $\mathbf{7 1 . 6 6}$ & 60 & 7.83 & 1.01 \\
& Pretest experimental & $\mathbf{8 6 . 2 3}$ & 60 & 7.81 & 1.00
\end{tabular}

Consequently, the increment in the scores is 14.56 as seen in table 16 . Much more, the p-value equals .000 and $(p=.000 p$ <.05), which is to say that there is a statistically significant difference between the results before and after applying CDIO treatment methodology. To put it differently, the students who got CDIO treatment performed better in the posttest than the pretest.

6.4.2 The Difference between the Male and the Female Students' Performance after Applying CDIO

This part represents a response to the second research question about the effect of the gender factor on the students' performance after applying the CDIO method. To do that, we first need to investigate the performance differences between the male and the female students of the experimental group before applying CDIO and after applying it. An independent samples t-test was applied on the pretest, the male students' mean score was found as 73.54 while the female students' mean score was 70.57, the mean difference was 2.96 and the p-value equals $.160(p=.160 . p>.05)$. In other words, there is no statistical significance of the value and there is no big difference between the boys and the girls' performance in the pretest. On the other hand, the results of the posttest according to the independent samples t-test indicate that the male students' mean score was found as 88.27 while the female students' mean score was 85.05 , the mean difference was 3.22 and the $p$-value equals $.125(p=.125 \mathrm{p}>.05)$. As a consequence of this, there is no effect on the gender factor on the participants' performance.

Table 6. The mean scores of the male and female students in both tests in the experimental group

\begin{tabular}{cccccc}
\hline Test & gender & N & Mean & Std. Deviation & Std. Error Mean \\
\hline Pretest & male & 22 & $\mathbf{7 3 . 5 4}$ & 8.18 & 1.74 \\
& female & 38 & $\mathbf{7 0 . 5 7}$ & 7.52 & 1.22 \\
Posttest & male & 22 & $\mathbf{8 8 . 2 7}$ & 7.15 & 1.52 \\
& female & 38 & $\mathbf{8 5 . 0 5}$ & 8.02 & 1.30
\end{tabular}

According to the data shown in Table 6 above, the male and the female participants performed almost the same in the pretest and likewise in the posttest. That means that the gender factor does not influence the results of our current research study.

\subsubsection{The Difference between the Experimental Group and the Control Group}

Here we answer the third research question and the most important point in the study. The essence of this study is to see whether there is a positive influence of implementing CDIO on the $11^{\text {th }}$-grade students in learning English or not. And to find an answer to our inquiry the collected data was analyzed with the assistance of IBM SPSS Statistics 23.0 and specifically, the one-way ANOVA test for comparing means between groups was applied on the pretest and the posttest with .05 significance level. The results show that the $p$-value in the pretest was $.657(p=.657 p>.05)$ this means that there is no statistical significance value and there is no statistical difference between the level of the students in the pretest before applying CDIO. Whereas the p-value in the posttest was. $00(\mathrm{p}=.000 \mathrm{p}<.05)$ this means that there is a statistical 
significance value and there is a statistical difference between the level of the students in the posttest after applying CDIO. Moreover, the means in the pretest of both groups are very similar to each other (71.66 for the experimental group and 72.26 for the control group) while the means of the posttest prove a considerable increase in the performance of the experimental group (86.23 for the experimental group and 74.56 for the control group) as in Table 7 .

Table 7. The mean scores of both groups in both tests

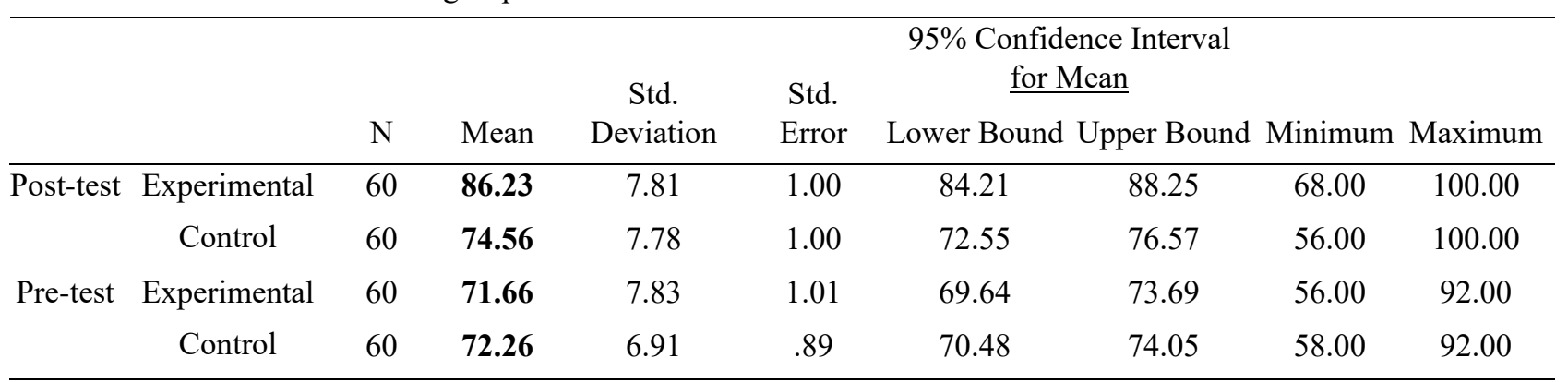

To add more, the mean difference between the experimental group and the control group in the pretest was -.60 while the mean difference between the experimental group and the control group in the posttest was 11.66. In other words, the control group performed better in the pretest at a rate of 0.60 and conversely, the experimental group performed better at a rate of 11.66 in the posttest after implementing the CDIO treatment. To put it briefly, there is a slight progression of the control group $(2.3 \%)$ between the pretest and the posttest; in contrast, there is a considerable progression of the experimental group (14.57\%) between the pretest and the posttest, and this leads us to say that this advancement can be seen as a consequence of using CDIO teaching method.

6.4.4 The Impact of Applying CDIO on Vocabulary, Grammar and Reading Comprehension

This section will answer the fourth research question with its three sub-questions about the role of the CDIO teaching model in boosting the $11^{\text {th }}$-grade students' skills in grammar, vocabulary, and reading. After finishing the CDIO method treatment process, the data of the pretest and posttest was collected and analyzed with the one-way ANOVA test for comparing means between groups as displayed in Table 8 .

Table 8 . The grammar, vocabulary, and reading mean scores and standard deviation in the pretest and posttest of both groups experimental and control

\section{ANOVA: Group Statistics}

\begin{tabular}{lccccc}
\multicolumn{1}{c}{ TEST } & GROUPS & $\mathrm{N}$ & Mean & Std. Deviation & Std. Error Mean \\
\hline Pretest & Control & 60 & $\mathbf{1 4 . 8 1}$ & 2.07 & .26 \\
GRAMMAR & Experimental & 60 & $\mathbf{1 4 . 8 0}$ & 1.92 & .24 \\
Posttest & Control & 60 & $\mathbf{1 5 . 1 8}$ & 1.91 & .24 \\
PrAMMAR & Experimental & 60 & $\mathbf{1 7 . 1 0}$ & 1.85 & .23 \\
Pretest & Control & 60 & $\mathbf{1 5 . 9 5}$ & 1.81 & .23 \\
VOCABULARY & Experimental & 60 & $\mathbf{1 6 . 0 0}$ & 1.69 & .21 \\
Posttest & Control & 60 & $\mathbf{1 6 . 0 3}$ & 1.59 & .20 \\
VOCABULARY & Experimental & 60 & $\mathbf{1 8 . 1 0}$ & 1.48 & .19 \\
Pretest READING & Control & 60 & $\mathbf{5 . 4 6}$ & 1.64 & .21 \\
& Experimental & 60 & $\mathbf{5 . 0 3}$ & 1.74 & .22 \\
Posttest READING & Control & 60 & $\mathbf{6 . 1 6}$ & 1.48 & .19 \\
& Experimental & 60 & $\mathbf{7 . 9 0}$ & 1.62 & .20
\end{tabular}




\subsubsection{The Influence of CDIO on Grammar Skills}

The grammar's mean score in the pretest was 14.80 later it increased in the posttest to became 17.10. So the mean difference between the two tests in the grammar section of the experimental group is 2.30. In addition to that, the $\mathrm{p}$-value is $.000(\mathrm{p}=.000 \mathrm{p}<.05)$ and when the value is smaller than .05 it implies that it has a statistical value (look at Table 9).

Table 9. The p-value and the mean score difference of the grammar section in both tests of the experimental group

\section{Paired Differences}

\begin{tabular}{|c|c|c|c|c|c|c|c|c|c|}
\hline & \multirow[b]{2}{*}{ Mean } & \multirow{2}{*}{$\begin{array}{c}\text { Std. } \\
\text { Deviation }\end{array}$} & \multirow{2}{*}{$\begin{array}{l}\text { Std. Error } \\
\text { Mean }\end{array}$} & \multicolumn{2}{|c|}{$\begin{array}{l}95 \% \text { Confidence Interva } \\
\text { of the Difference }\end{array}$} & \multirow[b]{2}{*}{$\mathrm{T}$} & \multirow[b]{2}{*}{ Df } & \multirow{2}{*}{$\begin{array}{c}\text { Sig. } \\
\text { (2-tailed) }\end{array}$} \\
\hline & & & & & Lower & Upper & & & \\
\hline Pair 1 & Experimental & & & & & & & & \\
\hline & $\begin{array}{l}\text { Grammar pretest } \\
\text { and posttest }\end{array}$ & 2.30 & 2.22 & .28 & 1.72 & 2.87 & 8.00 & 59 & .000 \\
\hline
\end{tabular}

In other words, there is a statistically significant difference in the grammar performance between the pretest and the posttest. Briefly, the students performed better in the posttest after they learned English through the disciplines of CDIO.

\subsubsection{The Influence of CDIO on the Vocabulary Skills}

The outcomes displayed in Table 8 signalize that there is an increment in the students' vocabulary performance, where the vocabulary mean score in the pretest was 16.00 afterward it raised in the posttest to become 18.10. Due to that, the amount of increment between the pretest and the posttest in the vocabulary section of the experimental group is 2.10 , additionally, the $\mathrm{p}$-value is $.000(\mathrm{p}=.000 \mathrm{p}<.05)$ as displayed in Table 10.

Table 10. The $p$-value and the mean score difference of the vocabulary section in both tests of the experimental group

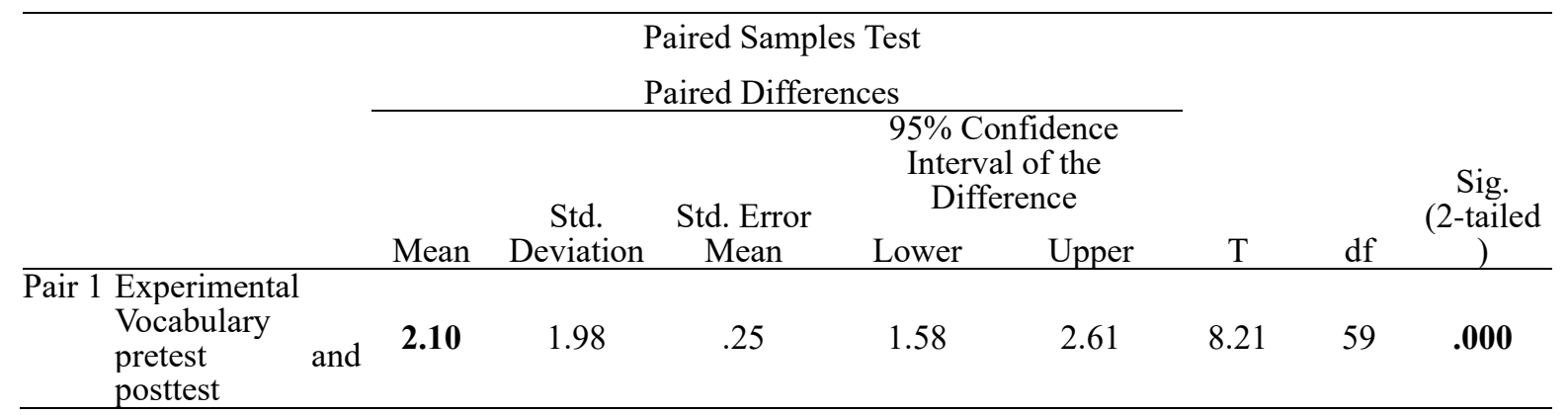

To put it differently, there is a statistically significant difference in the vocabulary performance of the experimental group between the pretest and the posttest. In short, there is a positive effect of learning vocabulary by using the CDIO method and there is an advancement in the students' performance after they received a CDIO treatment.

\subsubsection{The Influence of CDIO on the Reading Comprehension Skills}

The results presented in Table 8 point out that there is an advancement in the students' reading performance. The reading mean score in the pretest was 5.03, subsequently in the posttest, it increased to become 7.90 . Thus, the mean difference between the two tests in the reading section of the experimental group is 2.86 as pointed in Table 11.

Table 11. The p-value and the mean score difference of the reading section in both tests of the experimental group

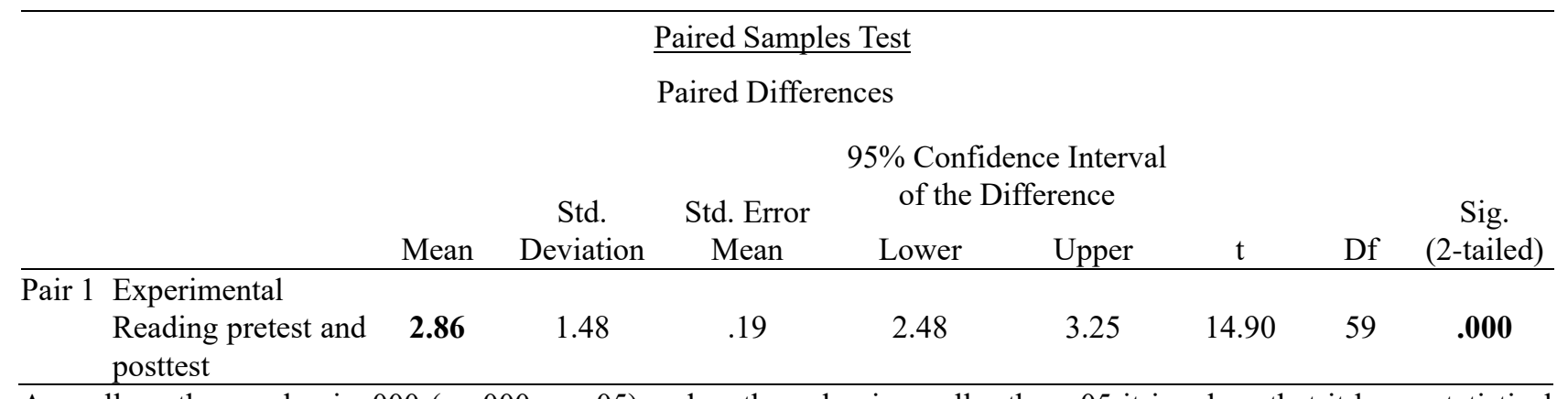

As well as, the $\mathrm{p}$-value is $.000(\mathrm{p}=.000 \mathrm{p}<.05)$ and as the value is smaller than .05 it involves that it has a statistical 
value. Simply put, there is a statistically significant difference in the reading performance between the pretest and the posttest.

\subsection{Discussions}

The first discussion point will be the results concerning the role of CDIO in raising the students' total scores. After the data was collected and analyzed, the results showed that the students performed better after learning English using CDIO in the rate of $14.45 \%$. To be said differently, the CDIO method has shown its efficiency in raising the level of the $11^{\text {th }}$-grade students' general level in English. The increase in the students' achievement proves that the CDIO can help the learners to broaden their knowledge and qualifications in English.

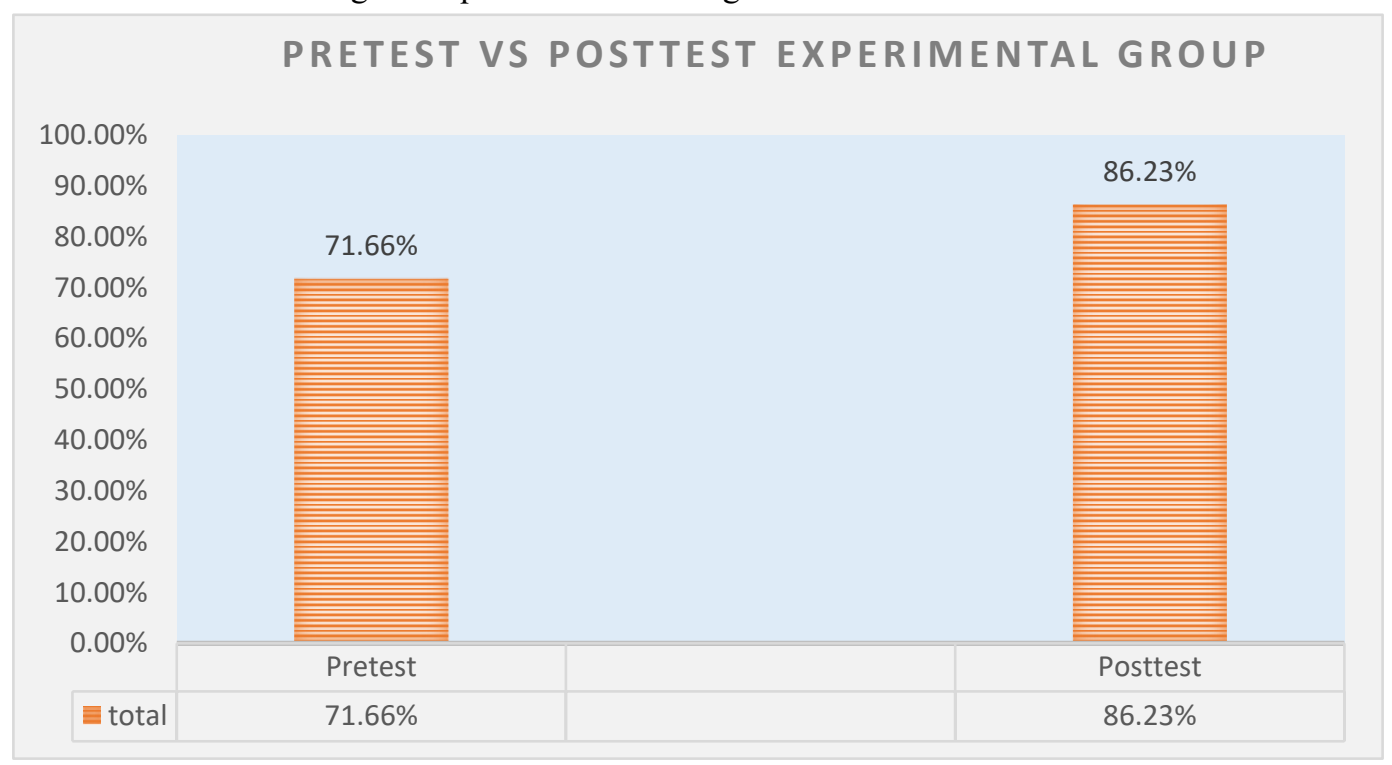

Figure 2. The increase of results between the pretest and posttest of the experimental group

The second point to discuss is the results collected from the role of the gender factor in this experimental study. The results reveal that the difference between the male and the female students in the pretest was $2.96 \%$, yet in the posttest, the difference was $3.22 \%$. Thereupon, the difference rate between the two genders has no significant statistics value, simply put, the male students and the female students performed almost the same in both tests and there was not any effect of the gender factor on the outcomes of the research study.

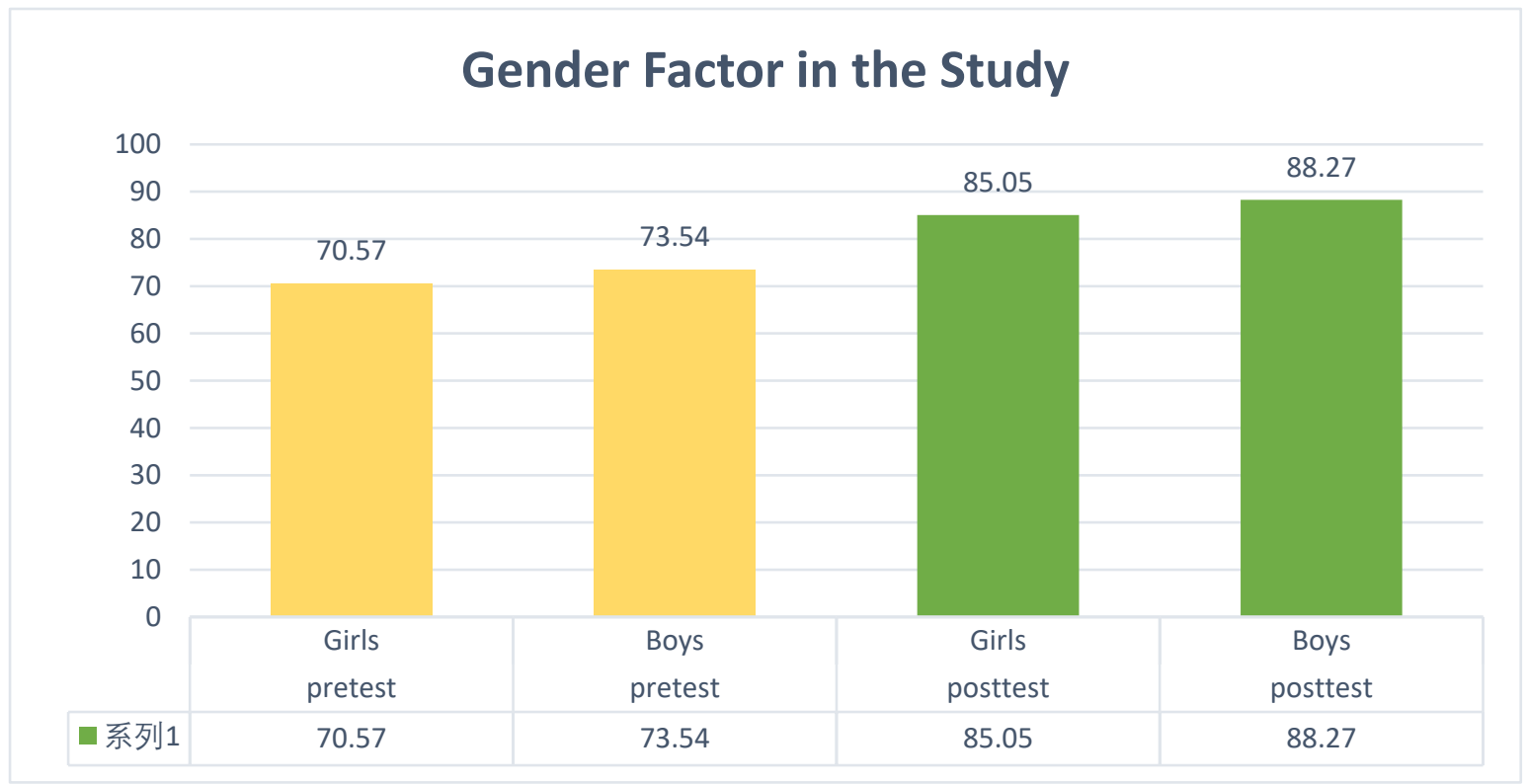

Figure 3. The gender factor effect on the results of the participants of the study 
Another point to discuss is the difference between the experimental group and the control group in terms of total scores. following that, Figure 4 exhibits that the control group average in the pretest was $72.26 \%$ and it stepped up to become $\mathbf{7 4 . 5 6 \%}$ in the posttest, accordingly, the increment amount is $\mathbf{2 . 3 \%}$. On the other hand, the experimental group average in the pretest was 71.66 while it jumped up to become $86.23 \%$ and as a consequence, the increment amount is $\mathbf{1 4 . 5 7 \%}$. Thus it is understandable that the progress in the control group was slight, whereas the progress in the experimental group was major. To explain it differently, the students who learned English in consonance with the instructions of CDIO have shown better performance and rendition than those who did not receive treatment from CDIO. All things considered, the CDIO has played a big role in developing the students' level and has shown a positive effect and leverage in learning English.

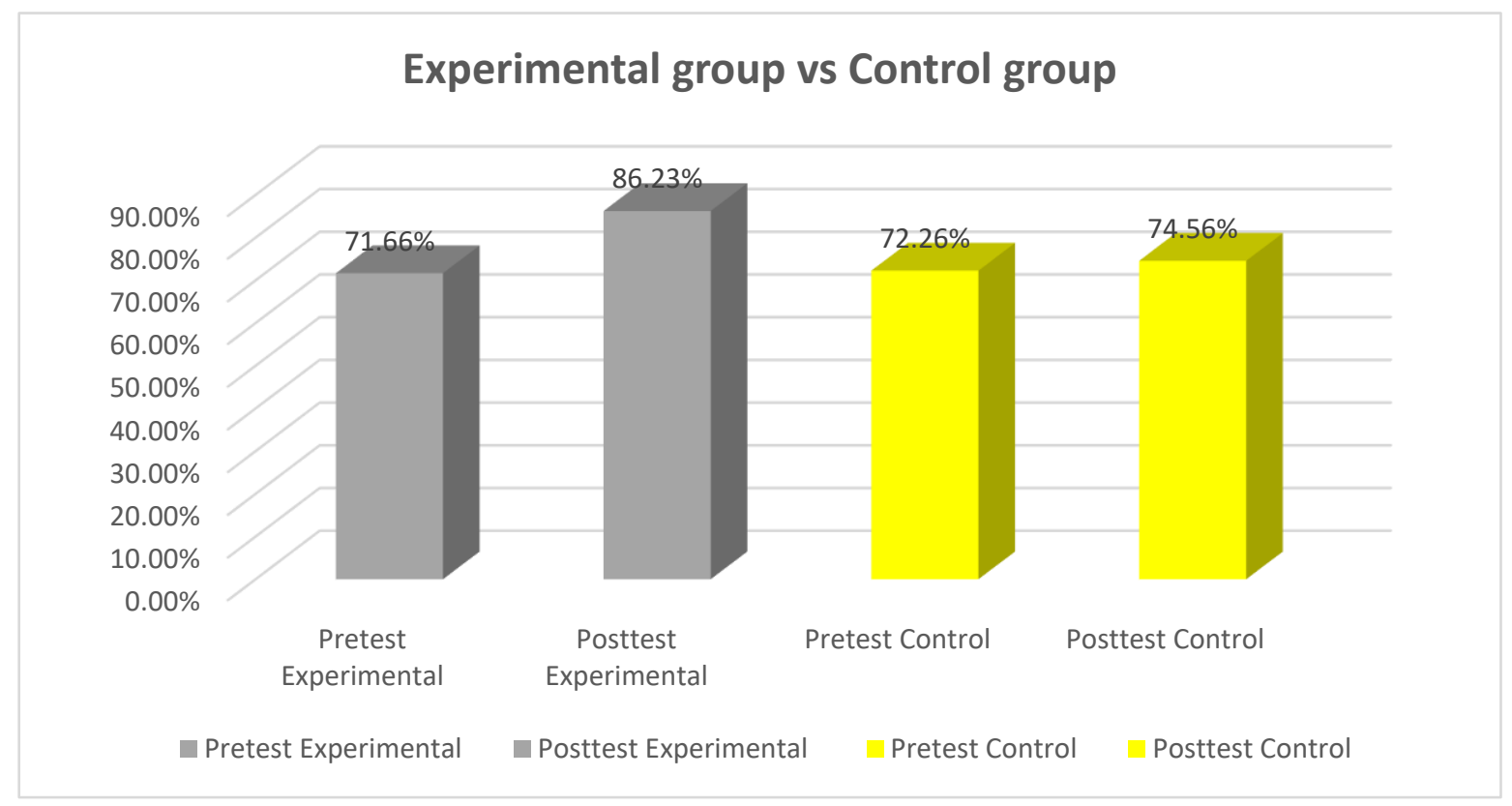

Figure 4. The participants' performance in the pretest and posttest of both groups

The last point to discuss is the results concerning the role of using CDIO in boosting the students' skills in grammar vocabulary and reading. The results exhibit that the participants' fulfillment developed in grammar at a rate of $4.60 \%$ where it was $29.80 \%$ in the pretest and it increased to $34.20 \%$ in the posttest. Similarly, the participants' achievement developed in vocabulary at a rate of $4.20 \%$ where it was $32.00 \%$ in the pretest and it increased to $36.20 \%$ in the posttest. On an equal footing, the participants' performance raised at a rate of $5.73 \%$ where it was $10.06 \%$ in the pretest and it promoted to $15.80 \%$ in the posttest. See Figure 5. 


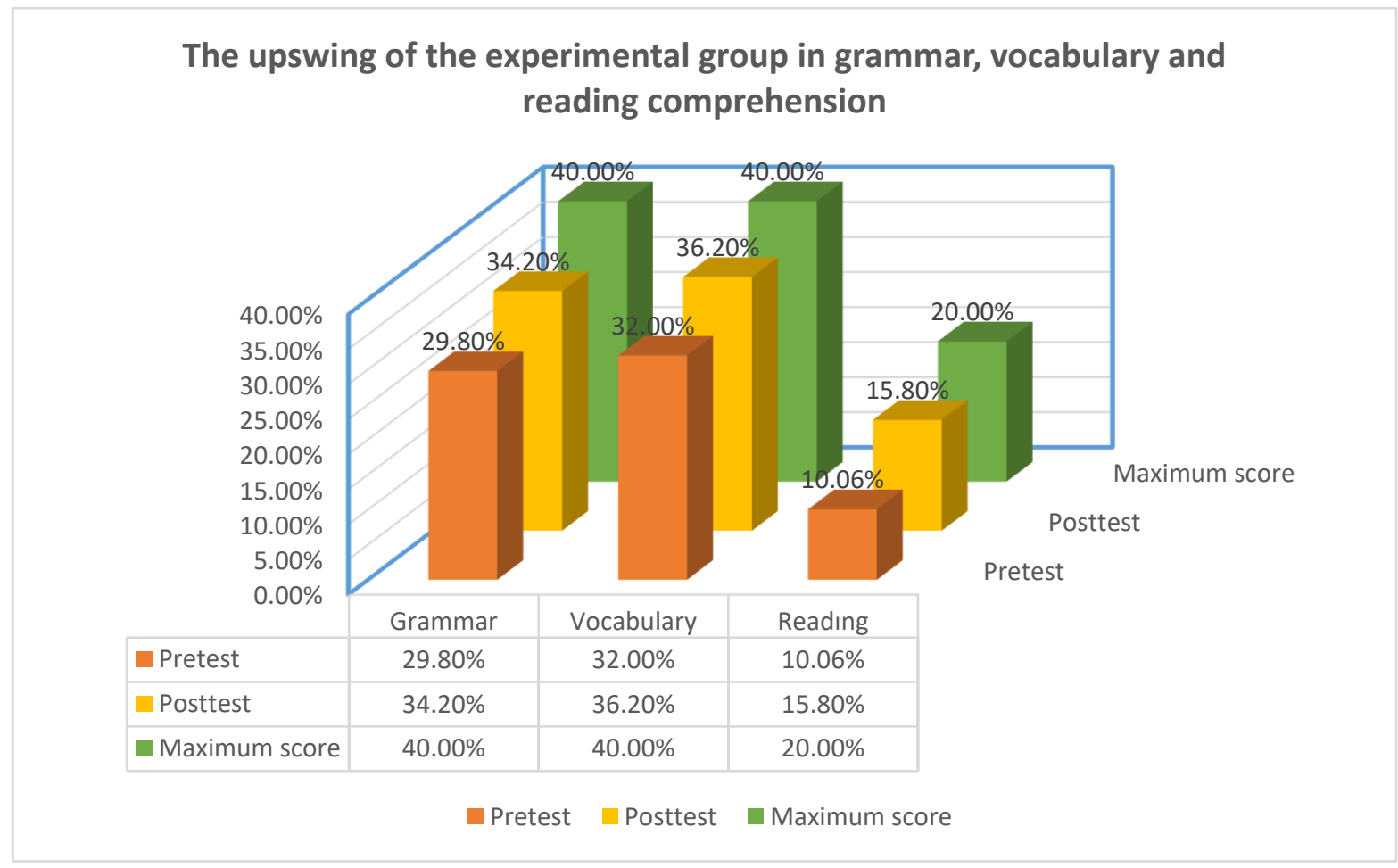

Figure 5. The experimental group accomplishment in grammar, vocabulary, and reading

In contrast, the findings of the control group demonstrated that there is no serious improvement in the level of the students. Numerically, their performance in the pretest was $29.63 \%$ in the grammar, $31.90 \%$ in vocabulary, and $10.93 \%$ in the reading comprehension; whereas in the posttest, their performance was $30.36 \%$ in grammar, $32.06 \%$ in vocabulary, and $12.33 \%$ in reading comprehension. Thereby, the growth between the pretest and the posttest is $0.73 \%$ in grammar, $0.16 \%$ in vocabulary, and $1.40 \%$ in reading comprehension (see Figure 6 ). This is tantamount to saying, there is no real increase in the performance of the students of the control group.

\section{The constancy of performance of the control group}

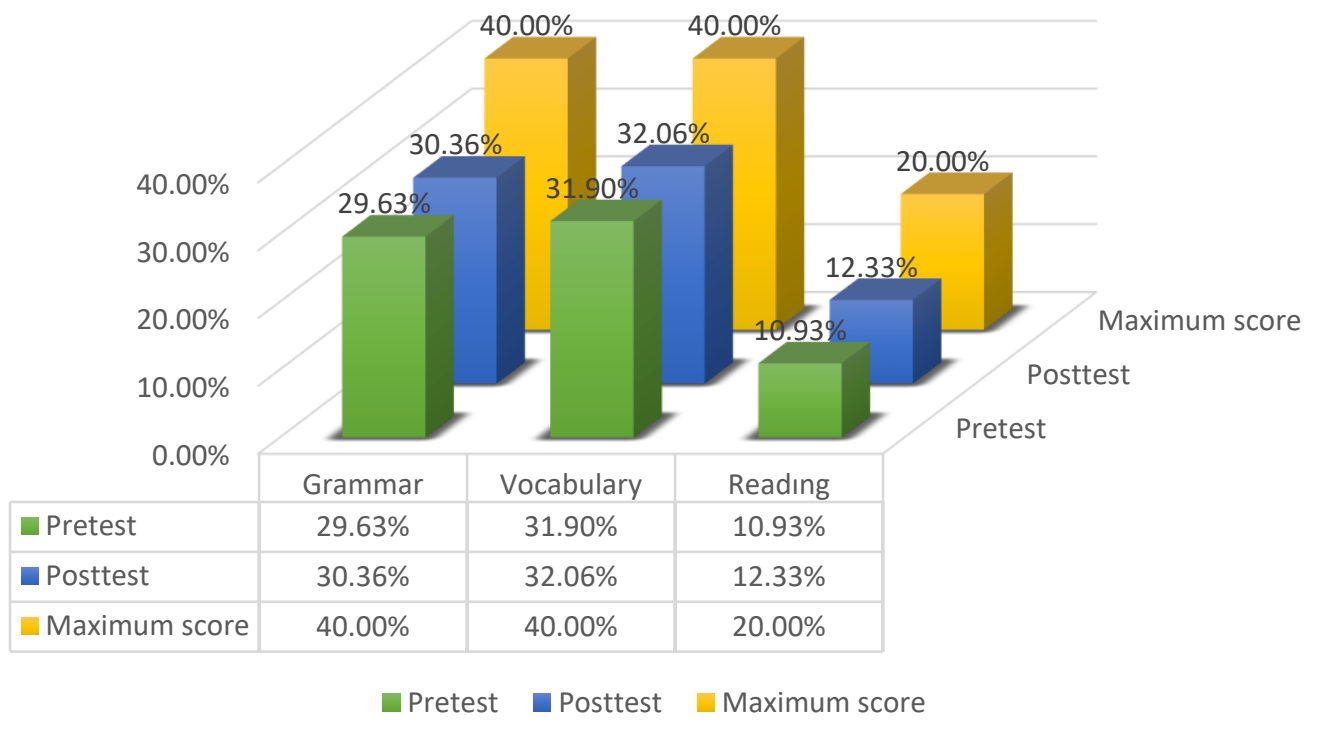

Figure 6. The control group performance stability in grammar, vocabulary, and reading

Assuredly, the CDIO played a key role in enhancing the students' performance in the grammar rules, vocabulary knowledge, and reading comprehension in particular and enhanced the students' general level in English. Ultimately, the 
students who got a CDIO treatment and learned English through the CDIO pedagogics performed better in the posttest and raised their awareness and knowledge profoundly in English.

In fact, there are many studies about using CDIO in the engineering field but there are very few studies about using CDIO in non-engineering fields. Here, we present some studies related to employing CDIO methodology in the engineering field, then some studies about implementing CDIO in non-engineering disciplines, finally, a study related to using CDIO in the language lessons.

On the engineering side, the Linköping University in Sweden made a study to compare the graduated students before implementing CDIO and the graduated students after implementing CDIO at Linköping University. And they found that the students who studied engineering through CDIO are better concerning project management, solving problems skill in the intense workload, and the teamwork experience (Edvardsson Stiwne \& Jungert, 2007).

Another study conducted by the Chalmers University of Technology on the alumni of mechanical engineering who learned according to CDIO. And the data of the study showed that these graduates had skills better than the graduates from other programs at Chalmers University in relation to designing, communication, and teamwork skills (Malmqvist, Bankel, Enelund, Gustafsson \& Knutson Wedel 2010).

On the non-engineering side, a study on adapting the CDIO framework to biomedicine education in the Department of Experimental and Clinical Medicine, Division of Cell Biology, Linköping University, Sweden, with the help of the Department of Electrical Engineering, Linköping University, Sweden. And the study results refer to the success of implementing CDIO in the biomedicine field with regard to the betterment of the students' ability to implement and operate disciplinary theory from one hand. And the betterment of the students' skills to meet the requirements of the employers in the biomedicine profession from the other hand (Fahlgren, Thorsell, Kågedal, Lindahl \& Gunnarsson, 2018).

One more study, the Faculty of Mass Communication Technology at the Rajamangala University of Technology, Thanyaburi, Thailand has adopted the CDIO framework as a context for producing professional hands-on graduates. The faculty has adopted the CDIO curriculum on six programs; namely, Multimedia, Digital Media, Television and Radio, Photography and Cinematography, Advertisement and Public Relations, and Digital Printing and Packaging Technology. After the application of CDIO, they confirmed that that the CDIO approach can be applied to non-engineering programs, moreover, they confirmed that CDIO-based education can enhance the competency of graduates and faculty members that meet stakeholders' requirements (Tangkijviwat, Sunthorn, Meeusah \& Kuptasthien, 2018).

On the English field-side, there is a study about applying CDIO in the English courses in higher education, the School of Foreign Languages, Leshan Normal University, Leshan, China. In this study, Wenwen and Yunfei (2018) confirm that applying the CDIO model in the English teaching field can improve some students' skills and capabilities. Skills like the innovation ability, the teamwork spirit, the related job knowledge of English, the ability to solve problems, the self-learning ability, the critical thinking ability, and the professional knowledge of English. Therefore, it is understandable that the Leshan University study supports the results and the findings of our current study.

Overall, all the statistics and analyses considered in this study show that using CDIO in high school can be successful. Even though CDIO is primarily an engineering teaching approach but this study approved that it also can be effective in teaching English. Finally, nevertheless, employing CDIO in the English language lessons in a high school is unique, and for the first time, this study has satisfactory results and it can be said that the CDIO method can be used in the same context educational institutions.

\section{Conclusions}

\subsection{Conclusions Related to the Students}

Notably, the CDIO has a positive effect on the students of the experimental group i.e. on their ability to learn a language. Furthermore, it has a positive effect on their understanding of English language grammar, vocabulary size, and reading comprehension skills. In addition, it should be noted that there is a major difference in the students' performance between the pretest and posttest. To be said differently, the students remarkably performed better in the posttest, thanks to the CDIO method and its effectiveness.

CDIO is a flexible method where it can be changed according to the needs of the learners, the environment, and the other factors. It is believed that the implementation of CDIO innovative teaching method raises the linguistic competence of the learners and raises the seven following practical skills: the innovation ability, the teamwork spirit, the related job knowledge of English, the ability to solve problems, the self-learning ability, the critical thinking ability, and the professional knowledge of English. 
This study proposes that using the CDIO concept in English language teaching can significantly strengthen the professional knowledge, studying confidence, and activate studying tendency of students. Meanwhile, the studying results of the professional English can also be enhanced through the CDIO framework together with a stable teaching effect of the professional skills of CDIO. It is also noteworthy that with the integration of the CDIO skills of communication, personal, interpersonal, and teamwork skills, the students of this study could raise their skills in English. It not only improves the students' comprehensive ability of communication, reading, writing, listening, and speaking, but also promotes the students' deep understanding of project-based teaching and team spirit. With regard to the before mentioned, integrating CDIO with teaching English in our study has achieved the desired effect. Therefore, it is clear that the integration of CDIO skills with learning English has borne fruits and reached its goals in this research. In addition to that, the CDIO not only improves the student's abilities but also improves the teacher's abilities, so using CDIO reaps rewards and benefits from students and teachers simultaneously.

\subsection{Conclusions Related to the Teachers}

As long as the researcher and the teacher is the same person in this experimental study, the researcher asserts that the CDIO improved his abilities in teaching English. In addition, CDIO helped him to learn some new teaching techniques, to become more innovative, and always to search for something new and this is supported by the study of Wenwen and Yunfei (2018). Moreover, it inspired him to be more practical and pragmatic. The researcher also learned from CDIO to create a student-centered atmosphere rather than a teacher-centered atmosphere in the classroom. Furthermore, the researcher learned to exploit the technology developments in the best way. The CDIO approach's first aim is to prepare qualified alumni, and the researcher kept that in his mind during the whole treatment process, again this is supported in the study of Wenwen and Baoguo 2020. Each instructor should keep that in his mind while teaching to implant the information in the students' minds so they can use this information not only in the near future but also in the far future after graduating. The goal of teaching is not to pass an exam; instead, the teachers need to transfer the knowledge in a way to settle in the intellect. The researcher learned from CDIO to be a 'smart street teacher' which means to be knowledgeable of the students and the environment and what is going around there, and that is what CDIO demands.

\subsection{Conclusions Related to the Possibility of Using CDIO in the Language Lessons}

It can be inferred from this experimental study that it is very possible to use CDIO in teaching English. Moreover, it is expected that CDIO will seize its place as a successful English language teaching method in the coming years. Coupled with this, the outcomes of this study may give futuristic ideas to English teachers and education foundations with respect to methodology, curriculum, and the materials used in instructing and job related knowledge. Furthermore, it is expected from CDIO, through its practicability and interdisciplinarity, to fill the gap between what is awaited from the English graduates and what is achieved in reality. From the standpoint of the practical life, the students understand what they have learnt through practice and they practice by what they have learnt, so they grasp a strong and solid understanding and they gain vigorous practical skills and that is the exact core of CDIO. Moreover, it is expected from CDIO as well to add something new to the field of ELT and helps to find the shortest and the idealist way of teaching English. In the light of that, we ought to encourage adopting CDIO for teaching on the general range and for teaching languages on the specific range.

\section{Recommendations for the Educational Institutions}

CDIO method is in ascending order among the teaching approaches in the education context, and CDIO is in use in more than 120 schools and universities around the world. The researcher strongly recommends the educational institutions to adopt this methodology. Besides, the Worldwide CDIO Initiative has an open access and channels to adopt the method, and the Figure 7 explains the process of adopting CDIO. Moreover, the CDIO Organization supplies, the institutions who wants to adopt the program after the six steps of acceptance, with materials, syllabus, curriculums, adopting guidance without any fee. Furthermore, The CDIO Initiative organizes annual International CDIO Conference in June each year to share collaboration and policies from one hand and to discuss the outcomes and the challenges of adopting CDIO program from the other hand. 


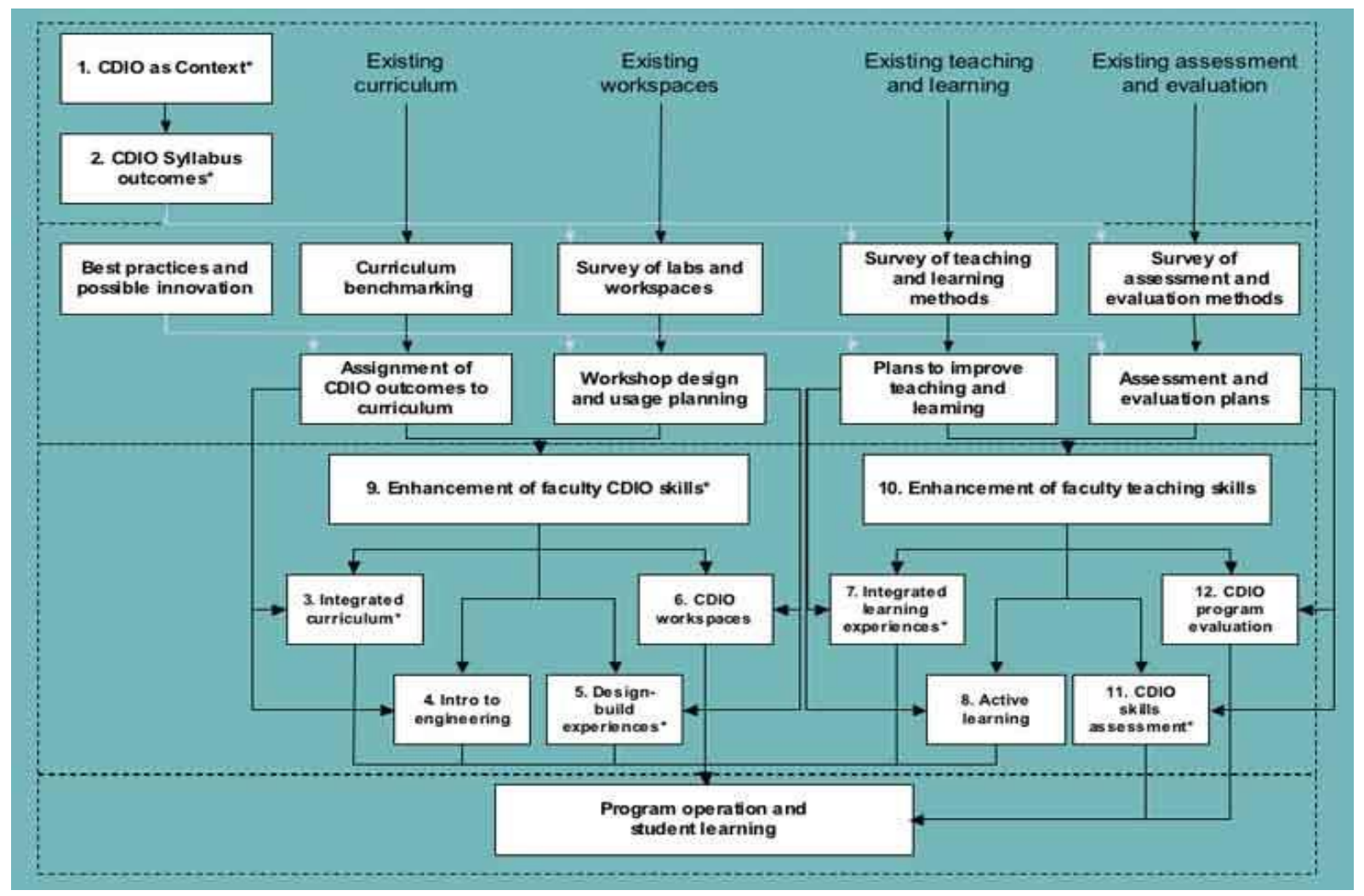

Figure 7. The adoption of CDIO process (http://www.cdio.org/)

Finally, the researcher of this study looks forward and fervently hopes that this research study will be the start whistle for the Turkish schools and universities to adopt this new method for teaching English and cultivate the outcomes of it. In the end, it is an invite to the Turkish education institutions to think about this innovative practical method for teaching languages and to use it in their curriculum as many big universal universities do around the world.

\section{References}

Bankel, J., Berggren, K. F., Blom, K., Crawley, E. F., Östlund, S., \& Wiklund, I. (2002). The CDIO Syllabus: A comparative study of expected student proficiency. The European Journal of Engineering Education, 28(3), 2003. https://doi.org/10.1080/0304379031000098274

Bankel, J., Berggren, K. F., Crawley, E. F., Engström, M., El Gaidi, K., Östlund, S., Soderholm, D., \& Wiklund, I. (2005). Benchmarking Engineering Curricula with the CDIO Syllabus. The International Journal of Engineering Education, 21(1). http://www.cdio.org

CDIO, the CDIO Initiative Standards, 1 May 2010 - The CDIO Standards v. 2.0. http://www.cdio.org.

CDIO, the CDIO Initiative Syllabus, http://www.cdio.org

Crawley, E. F. (2001). The CDIO Syllabus. A Statement of Goals for Undergraduate Engineering Education. Department of Aeronautics and Astronautics Massachusetts Institute of Technology January 2001. http://www.cdio.org

Crawley, E. F. (2002). Creating the CDIO Syllabus, a Universal Template for Engineering Education. Frontiers in Education, 2002(2), F3F-8-F3F-13. https://doi.org/10.1109/FIE.2002.1158202

Crawley, E. F., Lucas, W. A., Malmqvist, J., \& Brodeur, D. R. (2011). The CDIO Syllabus v2.0. An Updated Statement of Goals for Engineering Education. Proceedings of the 7th CDIO Conference, Technical University of Denmark, Copenhagen, June 20 - 23 2011. Retrieved from http://www.cdio.org/files/project/file/cdio_syllabus_v2.pdf

Crawley, E., F. Malmqvist, J., Östlund, S., Brodeur, D., \& Edstrom, K. (2014). Rethinking Engineering Education: The CDIO Approach, 2nd edition. New York: Springer-Verlag. https://doi.org/10.1007/978-3-319-05561-9

Delors, J., et al. (1996). Learning, the treasure within Report to UNESCO of the International Commission on Education for the twenty-first century. Paris: UNESCO Publishing. Available at http://www.unesco.org/delors/fourpil.htm. Accessed November 13, 2013. https://doi.org/10.7788/ijbe.1996.24.1.253

Dörnyei, Z. (2005). The psychology of the language learner: Individual differences in second language acquisition. 
MahwUrah, N.J: L. Erlbaum.

Edvardsson, S. E., \& Jungert, T. (2007) Engineering Students Experiences of the Transition from Study to Work, Proceedings of 2007 International CDIO Conference, Cambridge, MA, USA.

Fahlgren, A., Thorsell, A., Kågedal, K., Lindahl, M., \& Gunnarsson, S. (2018). Adapting the CDIO Framework to Biomedicine Education. Proceedings of the 14th International CDIO Conference, Kanazawa Institute of Technology, Kanazawa, Japan, June 28 - July 2, 2018.

Gu, P. H., Lu, X. H., \& Shen, M. F. (2008). CDIO Syllabus and Standards. Shantou: Shantou University Press.

Holliday, A. (1994). Appropriate Methodology and Social Context. Cambridge: Cambridge University Press.

Karanja, N. (2017). Why and How Self-Learning Is Important. Brighter Monday Kenya. 25 th September 2017. https:/www.brightermonday.co.ke/blog/self-learning/

Lightbown, P. M., \& Spada, N. (2013). How Languages Are Learned (fourth edition). Oxford: Oxford University Press.

Malmqvist, J., Bankel, J., Enelund, M., Gustafsson, G., \& Knutson, W. M. (2010). Ten Years of CDIO- Experiences from a Long-Term Education Development Process, Proceedings of 2010 International CDIO Conference, Montreal, Canada.

Passow, H. J. (2007). What competencies should engineering programs emphasize? A meta-analysis of practitioners' opinions informs curricular design. In Proceedings of the 3rd International CDIO Conference. Massachusetts Institute of Technology, Cambridge, Massachusetts, 2007. Available at http://www.cdio.org/knowledge-library Accessed November 13, 2013.

Richards, J. C. (2006). Materials development and research-making the connection. RELC Journal, 37(1)1, 5-26. https://doi.org/10.1177/0033688206063470

Sri Durga, V. S. (2018). The Need of English Language Skills for Employment Opportunities. Journal for Research Scholars and Professional of English Language Teaching, 7(2).

Tang, H. J. (2009). On Cultivating Professional Practical Abilities of Undergraduates in the Course of Integrated English. Shandong Foreign Language Teaching Journal, 131(4), 49-53.

Tangkijviwat, U., Sunthorn, W., Meeusah, N., \& Kuptasthien, N. (2018). CDIO-based curriculum development for non-engineering programs at mass communication technology faculty. Proceedings of the 14th International CDIO Conference, Kanazawa Institute of Technology, Kanazawa, Japan, June 28 - July 2, 2018.

Ur, P. (2011). 'Grammar teaching: research, theory and practice' in E. Hinkel (ed.). Handbook of Research in Second Language Teaching and Learning, Vol. 2. New York, NY: Routledge.

Waters, A. (2009). Ideology in applied linguistics for language teaching. Applied Linguistics, 30(1), $138-143$. https://doi.org/10.1093/applin/amp005

Wenwen, X., \& Baoguo, Z. (2020). Exploration and Application of CDIO Teaching Mode in Integrated English Teaching. Sino-US English Teaching, 17(1), 1-7. https://doi.org/10.17265/1539-8072/2020.01.001

Wenwen, X., \& Yunfei, G. (2018). Practical Abilities Improved by CDIO Teaching Mode Taking the Course of Integrated English as an Example, Canadian Center of Science and Education, September 21, 2018. https://doi.org/10.5539/elt.v11n10p109

Womack, J. P., \& Jones, D. T. (1996). Beyond Toyota: How to root out waste and pursue perfection. Harvard Business Review, 74(5), 140-158.

Zheng, C. (2013). A Syllabus Design of College Integrated English Class in China-On the Integration of Task-based teaching and Classroom-based Assessment. International Journal of Applied Linguistics \& English Literature. ISSN 2200-3592 (Print), ISSN 2200-3452(Online), 2(6), November2013. https://doi.org/10.7575/aiac.ijalel.v.2n.6p.36

Zhu, F. (2010). A Study of Project Teaching Approach in China-Also on Applicability of Project Teaching Approach to Foreign Language Teaching in China. Theory and Practice of Education, 30(9), 54-56.

\section{Copyrights}

Copyright for this article is retained by the author(s), with first publication rights granted to the journal.

This is an open-access article distributed under the terms and conditions of the Creative Commons Attribution license which permits unrestricted use, distribution, and reproduction in any medium, provided the original work is properly cited. 